\title{
Mitochondrial diseases in North America
}

\author{
An analysis of the NAMDC Registry
}

Emanuele Barca, MD, PhD, Yuelin Long, MS, Victoria Cooley, MS, Robert Schoenaker, MD, BS, Valentina Emmanuele, MD, PhD, Salvatore DiMauro, MD, Bruce H. Cohen, MD, Amel Karaa, MD, Georgirene D. Vladutiu, PhD, Richard Haas, MBBChir, Johan L.K. Van Hove, MD, PhD, Fernando Scaglia, MD, Sumit Parikh, MD, Jirair K. Bedoyan, MD, PhD, Susanne D. DeBrosse, MD, Ralitza H. Gavrilova, MD, Russell P. Saneto, DO, PhD, Gregory M. Enns, MBChB, Peter W. Stacpoole, MD, PhD, Jaya Ganesh, MD, Austin Larson, MD, Zarazuela Zolkipli-Cunningham, MD, Marni J. Falk, MD, Amy C. Goldstein, MD, Mark Tarnopolsky, MD, PhD, Andrea Gropman, MD, Kathryn Camp, MS, RD, Danuta Krotoski, PhD, Kristin Engelstad, MS, Xiomara Q. Rosales, MD, Joshua Kriger, MS, Johnston Grier, MS, Richard Buchsbaum, John L.P. Thompson, PhD, and Michio Hirano, MD

Neurol Genet 2020;6:e402. doi:10.1212/NXG.0000000000000402

\begin{abstract}
Objective

To describe clinical, biochemical, and genetic features of participants with mitochondrial diseases (MtDs) enrolled in the North American Mitochondrial Disease Consortium (NAMDC) Registry.
\end{abstract}

\section{Methods}

This cross-sectional, multicenter, retrospective database analysis evaluates the phenotypic and molecular characteristics of participants enrolled in the NAMDC Registry from September 2011 to December 2018. The NAMDC is a network of 17 centers with expertise in MtDs and includes both adult and pediatric specialists.

\section{Results}

One thousand four hundred ten of 1,553 participants had sufficient clinical data for analysis. For this study, we included only participants with molecular genetic diagnoses $(n=666)$. Age at onset ranged from infancy to adulthood. The most common diagnosis was multisystemic disorder (113 participants), and only a minority of participants were diagnosed with a classical mitochondrial syndrome. The most frequent classical syndromes were Leigh syndrome (97 individuals) and mitochondrial encephalomyopathy, lactic acidosis, and stroke-like episodes (71 individuals). Pathogenic variants in the mitochondrial DNA were more frequently observed (414 participants) than pathogenic nuclear gene variants (252 participants). Pathogenic variants in 65 nuclear genes were identified, with POLG1 and PDHA1 being the most commonly affected. Pathogenic variants in 38 genes were reported only in single participants.

\section{Conclusions}

The NAMDC Registry data confirm the high variability of clinical, biochemical, and genetic features of participants with MtDs. This study serves as an important resource for future enhancement of $\mathrm{MtD}$ research and clinical care by providing the first comprehensive description of participant with $\mathrm{MtD}$ in North America.

From the Department of Neurology (E.B., V.E., S.D., K.E., X.Q.R., M.H.), Columbia University Medical Center, New York; Department of Biostatistics (Y.L., V.C., J.K., J. Grier, R.B., J.L.P.T.), Mailman School of Public Health, Columbia University, New York; Radboudumc (R.S.), Nijmegen, The Netherlands; Department of Pediatrics (B.H.C.), Northeast Ohio Medical University and Akron Children's Hospital; Genetics Unit (A.K.), Massachusetts General Hospital, Boston; Department of Pediatrics (G.D.V.), State University of New York at Buffalo; Departments of Neurosciences and Pediatrics (R.H.), University of California at San Diego; Department of Pediatrics (J.L.K.V.H., A.L.), University of Colorado School of Medicine, Aurora; Department of Molecular and Human Genetics (F.S.), Baylor College of Medicine, Houston, TX; Texas Children's Hospital (F.S.), Houston; Joint BCM-CUHK Center of Medical Genetics (F.S.), Prince of Wales Hospital, ShaTin, New Territories, Hong Kong; Department of Neurology (S.P.), Cleveland Clinic, OH; Departments of Genetics and Genome Sciences and Pediatrics (I.K.B., S.D.D.), and Center for Human Genetics, University Hospitals Cleveland Medical Center, Case Western Reserve University, OH; Departments of Neurology and Clinical Genomics (R.H.G.), Mayo Clinic, Rochester, MN; Department of Neurology (R.P.S.), University of Washington, Seattle Children's Hospital; Department of Pediatrics (G.M.E.), Stanford University, Palo Alto, CA; Department of Medicine (P.W.S.), University of Florida at Gainesville; Genetics and Genomic Sciences at the Icahn School of Medicine at Mount Sinai (J. Ganesh), New York; Mitochondrial Medicine Frontier Program (Z.Z.-C., M.J.F., A.C.G.), Division of Human Genetics, The Children's Hospital of Philadelphia and University of Pennsylvania Perelman School of Medicine; University of Pennsylvania Perelman School of Medicine (Z.Z.-C.), Philadelphia; Department of Neurology (M.T.), McMasters University, Toronto, Ontario, Canada; Department of Neurology (A.G.), Children's National Health Network, Washington, DC; Office of Dietary Supplements (K.C.), National Institutes of Health, Bethesda, MD; and Eunice Kennedy Shriver National Institute of Child Health and Human Development (D.K.), National Institutes of Health, Bethesda, MD. 


\section{Glossary}

$\mathrm{CoQ}_{\mathbf{1 0}}=$ coenzyme $\mathrm{Q}_{10} ; \mathbf{C O X}=$ cytochrome $c$ oxidase $; \mathbf{c P E O}=$ chronic progressive external ophthalmoplegia; IRB = institutional review board; LS = Leigh syndrome; LHON = Leber hereditary optic neuropathy; MELAS = mitochondrial encephalomyopathy, lactic acidosis, and stroke-like episodes; MERRF = myoclonus epilepsy with ragged red fibers; MtD = mitochondrial disease; mtDNA = mitochondrial DNA; NAMDC = North American Mitochondrial Disease Consortium; nDNA = nuclear DNA; OxPhos = oxidative phosphorylation; PDC = pyruvate dehydrogenase complex; SLE = stroke-like episode; TP = thymidine phosphorylase.

Mitochondria are the organelles that generate cellular energy (adenosine triphosphate) via oxidative phosphorylation (OxPhos). OxPhos is an elaborate multiprotein machine composed of a series of enzyme complexes embedded in the inner mitochondrial membrane (complex I-V). ${ }^{1}$ Because virtually all tissues require mitochondria to function, mitochondrial dysfunction manifests commonly as multisystem disorders, with frequent involvement of high-energy demand tissues, such as brain, muscle, and heart. ${ }^{2}$ The OxPhos system consists of 85 subunits and is under the control of 2 genomes, the nuclear DNA (nDNA) and mitochondrial DNA (mtDNA). Mitochondrial diseases (MtDs) can arise due to pathogenic variants in either of the 2 genomes. ${ }^{3}$ Because of the genetic complexity and the multiple biochemical functions of these organelles, MtDs are phenotypically and genetically heterogeneous. Because of this vast diversity, these disorders are challenging to diagnose, manage clinically, and investigate scientifically. Epidemiologically, $\mathrm{MtDs}$ are considered rare diseases, but among rare disorders, they are relatively frequent, with an overall estimated prevalence of 11.5:100,000. ${ }^{3}$ In totality, MtDs represent the most prevalent group of inherited neurologic disorders. ${ }^{4}$ Disease registries constitute a cornerstone of $\mathrm{MtDs}$ patient care because they help to establish a reliable picture of the distribution and characteristics of the participants, focus resources, and gather accurate data for efficient clinical mechanistic studies and therapeutic trials. ${ }^{5}$ This article reviews the spectrum of clinical, biochemical, and molecular genetic features of MtD participants enrolled in the North American Mitochondrial Disease Consortium (NAMDC) Registry (hereafter referred to as the Registry).

\section{Methods}

\section{Standard protocol approvals, registrations, and patient consents}

The NAMDC is an NIH-funded collaborative effort of 17 North American medical centers, which work in close partnership with the United Mitochondrial Disease Foundation and other patient advocacy groups. Since 2011, the NAMDC has maintained a Registry that has collected clinical, biochemical, histologic, and molecular genetic data on participants with MtDs. The Registry protocol was approved by the $\mathrm{NIH}$ and the NAMDC central Institutional Review Board (IRB) with local context review at each NAMDC site (NCT01694940). To enroll, participants had to visit an experienced clinician at one of the sites for a review of medical history, physical examination, and laboratory tests and provide written consent using IRB-approved forms. Clinicians input data using a secure web-based data entry system. Data were collected through December 1, 2018.

\section{Data availability}

The NAMDC Clinical Registry data are stored in a secure database and are available to other investigators on submission of a data use application and approval by the NAMDC Data Use Committee.

\section{Clinical diagnosis}

Participants are enrolled in the Registry based on the NAMDC site investigators' clinical diagnoses of MtDs. Diagnoses are based on established and published clinical criteria. ${ }^{6,7}$ Twenty-five different clinical diagnoses were coded: 15 classical mitochondrial clinical syndromes and 8 with an association of symptoms and signs commonly observed in mitochondrial participants (table 1) ${ }^{8-12}$ Some of the syndromes require an association of clinical and radiologic findings, e.g., for the diagnosis of leukoencephalopathy, white matter lesions evident on brain MRI are typically associated with cognitive impairment, long-tract signs, or both. Encephalopathy was defined by the presence of dementia, seizures, corticospinal tract dysfunction, movement disorders, or combinations of these manifestations due to cerebral pathology.

Two nonspecific groups of participants with complex clinical manifestations that do not fall in any of the other categories are (1) multisystemic and (2) other clinical disorders. For multisystemic disease, clinical manifestations must involve at least 3 organs with a progressive clinical course that does not otherwise conform to a classical phenotype. Participants without clinical manifestations were classified as asymptomatic carriers, which are not included in this analysis.

\section{Clinical, biochemical, and laboratory data}

Clinical, laboratory, and biochemical data were collected: deficiencies of OxPhos activities, coenzyme $\mathrm{Q}_{10}\left(\mathrm{CoQ}_{10}\right)$, pyruvate dehydrogenase complex (PDC), or thymidine phosphorylase (TP).

\section{Molecular genetics}

nDNA pathogenic variants as well as mtDNA pathogenic point variants, single and multiple large-scale deletions, and depletion were recorded. All genetic variants in the database were also 
Table 1 Demographic, clinical, biochemical, and genetic characteristics of the North American Mitochondrial Disease Consortium Clinical Registry participants $(\mathrm{N}=666)$

\begin{tabular}{|c|c|}
\hline Characteristic (participants) & Frequency (\%) \\
\hline \multicolumn{2}{|l|}{ Sex } \\
\hline Female & $380(57.1)$ \\
\hline Male & $285(42.8)$ \\
\hline Missing & $1(0.2)$ \\
\hline \multicolumn{2}{|l|}{ Racial composition } \\
\hline White & $567(85.1)$ \\
\hline Asian & $24(3.6)$ \\
\hline More than one & $22(3.3)$ \\
\hline Black/African American & $19(2.9)$ \\
\hline Other & $33(5.0)$ \\
\hline Missing & $1(0.2)$ \\
\hline \multicolumn{2}{|l|}{ Age at onset } \\
\hline$<2 y$ & $198(29.7)$ \\
\hline$\geq 2$ to $<5 y$ & $83(12.5)$ \\
\hline$\geq 5$ to $<12 y$ & $76(11.4)$ \\
\hline$\geq 12$ to $<18 y$ & $52(7.8)$ \\
\hline$\geq 18 y$ & $180(27.0)$ \\
\hline Missing & 77 (11.6) \\
\hline \multicolumn{2}{|l|}{ Clinical syndrome } \\
\hline Multisystemic syndrome & $113(17.0)$ \\
\hline$L^{a}$ & $97(14.6)$ \\
\hline Other clinical syndrome & $75(11.3)$ \\
\hline MELAS ${ }^{a}$ & $71(10.7)$ \\
\hline Encephalopathy & $38(5.7)$ \\
\hline $\mathrm{CPEO}^{\mathrm{a}}$ & $37(5.6)$ \\
\hline Encephalomyopathy & $32(4.8)$ \\
\hline LHON $^{a}$ & $28(4.2)$ \\
\hline Myopathy & $25(3.8)$ \\
\hline SANDO $^{a}$ & $19(2.9)$ \\
\hline CPEO $^{a}$ & $18(2.7)$ \\
\hline $\mathrm{KSS}^{\mathrm{a}}$ & $17(2.6)$ \\
\hline MIDD $^{a}$ & $16(2.4)$ \\
\hline Alpers syndrome ${ }^{a}$ & $15(2.3)$ \\
\hline MERRF $^{a}$ & $13(2.0)$ \\
\hline Pearson syndrome $^{a}$ & $10(1.5)$ \\
\hline MNGIE $^{a}$ & $10(1.5)$ \\
\hline
\end{tabular}

Table 1 Demographic, clinical, biochemical, and genetic characteristics of the North American Mitochondrial Disease Consortium Clinical Registry participants $(\mathrm{N}=666)$ (continued)

\begin{tabular}{ll}
\hline Characteristic (participants) & Frequency (\%) \\
\hline NARP $^{a}$ & $8(1.2)$ \\
\hline Hepatocerebral syndrome & $6(0.9)$ \\
\hline Maternal inherited deafness & $5(0.8)$ \\
\hline Cardiomyopathy & $5(0.8)$ \\
\hline Leukoencephalopathy & $4(0.6)$ \\
\hline RIM with Cox deficiency & $2(0.3)$ \\
\hline Barth syndrome $^{\text {a }}$ & $2(0.3)$ \\
\hline
\end{tabular}

Biochemical deficiencies (114 recorded;

not recorded in 552 [82.9\%])

\begin{tabular}{ll}
\hline Isolated complex I & $18(2.7)$ \\
\hline Isolated complex II & $1(0.2)$ \\
\hline Isolated complex III & $1(0.2)$ \\
\hline Isolated complex IV & $14(2.1)$ \\
\hline Isolated complex V & $5(0.8)$ \\
\hline Combined RCE complexes & $21(3.2)$ \\
\hline CoQ 10 & $2(0.3)$ \\
\hline TP & $8(1.2)$ \\
\hline PDC & $44(6.6)$ \\
\hline Molecular genetic information & $414(62.2)$ \\
\hline mtDNA pathogenic variants & $252(37.8)$ \\
\hline nDNA pathogenic variants
\end{tabular}

Abbreviations: $\mathrm{CoQ}_{10}=$ coenzyme $\mathrm{Q}_{10} ; \mathrm{CPEO}=$ chronic progressive external ophthalmoplegia; KSS = Kearns-Sayre syndrome; LHON = Leber hereditary optic neuropathy; LS = Leigh syndrome; MELAS = mitochondrial encephalomyopathy, lactic acidosis, and stroke-like episodes; MERRF = myoclonus epilepsy with ragged red fibers; MIDD = maternal inherited diabetes and deafness, also known as diabetes and deafness, DAD; MNGIE = mitochondrial neurogastrointestinal encephalopathy; $m t D N A=$ mitochondrial DNA: $\mathrm{NARP}=$ neuropathy, ataxia, and retinitis pigmentosa; $\mathrm{nDNA}=$ nuclear DNA $\mathrm{PDC}=$ pyruvate dehydrogenase complex; RCE = respiratory chain enzyme; RIM with COX deficiency = reversible infantile myopathy with cytochrome $c$ oxidase deficiency; SANDO = sensory ataxic neuropathy with dysarthria and ophthalmoparesis; TP = thymidine phosphorylase.

Multisystemic syndrome is defined by clinical manifestations involving at least 3 organs. Other clinical syndrome is defined as a disorder not conforming to one of the classical syndromes or multisystemic syndrome. ${ }^{a}$ Classical syndromes.

assessed for pathogenicity using MseqDR (mseqdr.org), and variants in the POLG1 gene were assessed using the NIH-based POLG1 mutation database (tools.niehs.nih.gov/polg/).

\section{Statistical analysis}

The Fisher exact test (SAS 9.4: SAS Institute Inc., Cary, NC) was used in the comparisons of participants with different genetic features, and Holm adjustment (R 3.5.1: Bell Laboratories, New Providence, NJ) for multiple comparisons. 


\section{Results}

Of the 1,533 total participants enrolled in the Registry (January 2011-December 2018), 1,410 had complete data on clinical manifestations, biochemistry, and genetics. Genetic diagnosis was available for 722 participants. After the exclusion of 56 asymptomatic carriers, 666 genetically diagnosed symptomatic individuals remained for analysis (table 1 ).

Demographic characteristics are summarized in table 1. Age at disease onset showed a bimodal distribution with peaks below age 2 years and in adulthood ( $\geq 18$ years). The most frequent classical diagnoses were Leigh syndrome (LS) (97 participants), mitochondrial encephalomyopathy, lactic acidosis, and stroke-like episodes (MELAS) (71 participants), chronic progressive external ophthalmoplegia (cPEO) and $\mathrm{CPEO}$ with other organ-system manifestations (beside skeletal muscle involvement) (cPEO+) (55 participants), and Leber hereditary optic neuropathy (LHON) (28 participants) (table 1). A large proportion of participants had nonspecific disease syndromes (298 participants). These nonspecific disorders included multisystemic (113 participants) and other clinical syndromes (75 participants) (table 1). The prevalence of nonspecific diagnoses was high in both the pediatric $(<18$ years) and adult population ( $\geq 18$ years).

\section{Classical mitochondrial syndromes}

\section{Leigh syndrome}

Ninety-seven participants had LS. Disease onset was seen predominantly in infancy ( $<2$ years in 55 participants) (table 2 ). The most frequent manifestations were developmental delay ( 84 participants), followed by developmental regression (42 participants). Other neurologic manifestations included ataxia (44 participants), dystonia (44 participants), and seizures (38 participants). Skeletal muscle (73 participants) and the gastrointestinal tract (26 participants) were also commonly affected (table 2). Brain imaging showed bilateral basal ganglia involvement in 55 participants and/or lesions of the brainstem (27 participants). Variants in both nuclear and mitochondrial genomes were identified: $52 \mathrm{mtDNA}$ and 45 nDNA pathogenic variants in 21 different nuclear genes (figure 1, table 2).

\section{Myoclonus epilepsy with ragged red fibers}

Thirteen participants had a clinical diagnosis of myoclonus epilepsy with ragged red fibers (MERRF). Six had childhood onset. Developmental problems were reported in 5 participants (table 2) and neuropathy in 4 (table e-2, links.lww. com/NXG/A226). Six participants had multiple lipomatosis. All participants had a pathogenic variant in the mitochondrial MTTK gene, with the prototypical m.8344A $>\mathrm{G}$ pathogenic variant (figure 1) in 9 of them.

\section{Mitochondrial encephalomyopathy, lactic acidosis, and stroke-like episodes}

Seventy-one participants (28 males, 42 females, and 1 unknown) had MELAS. The majority had disease onset in adulthood (table 2). Apart from key clinical findings in CNS and skeletal muscle involvement, heart abnormalities were recorded (21 participants), with cardiac arrhythmias being the most prevalent (table 2, table e-1, links.lww.com/NXG/ A226). Gastrointestinal tract manifestations and diabetes mellitus were also commonly reported (table 2 , table e-2). In addition to stroke-like episodes (SLEs), the most common CNS manifestations were seizures, migraine, and ataxia (tables e-1 and e-2). Thirty-nine participants had constitutional symptoms (short stature and low body mass index) (table 2). Genetically, m.3243A $>\mathrm{G}$ in the mitochondrial MTTL1 gene was the most frequently observed pathogenic variant. In addition, 10 of 69 participants (14.5\%) with POLG pathogenic variants manifested SLEs, but only 1 was diagnosed with MELAS.

\section{Chronic progressive external ophthalmoplegia}

Fifty-five participants were diagnosed with $\mathrm{cPEO} / \mathrm{cPEO}+(18$ cPEO and $37 \mathrm{cPEO}+$ ). The majority were adults (table 2 ). Muscle involvement in cPEO was not confined to the extrinsic ocular muscles, as skeletal myopathy (10 participants) and dysphagia (4 participants) were also observed. Participants with cPEO+ frequently had CNS symptoms (24 participants), with ataxia and hearing loss being the most prevalent (table e-1, links.lww.com/NXG/A226). Both mtDNA and nDNA pathogenic variants have been observed (figure 1). Variants in mtDNA were more frequent than nDNA in both groups ( $14 \mathrm{cPEO}$ participants and $23 \mathrm{cPEO}+$ participants). Single large-scale mtDNA deletions were present in 12 participants with $\mathrm{cPEO}$ and 15 with $\mathrm{cPEO}+$. Although infrequently identified, nDNA pathogenic variants were more common in the $\mathrm{CPEO}+(11$ participants $)$ group; the majority had variants in POLG1 (6 cPEO+ and 2 cPEO).

\section{Leber hereditary optic neuropathy}

Twenty-eight participants were diagnosed with LHON; 23 were males. Involvement of other organ-systems was commonly reported. The most frequent extraocular affected organ was the CNS (18 participants) with a constellation of different manifestations including seizures (3 participants), migraine headaches (3 participants), hearing loss ( 2 participants), and ataxia (1 participant) (table e-1, links.lww.com/NXG/A226). Of 28 participants with a genetic diagnosis, only 1 had a pathogenic nDNA variant; that participant was misdiagnosed before molecular genetic testing.

\section{Biochemical diagnosis}

Biochemical deficiencies were recorded in 114 participants (table 1). Data on OxPhos activity were available in 666 individuals, of which defects were identified in 60 . Combined respiratory enzyme deficiencies were the most common abnormalities (21 participants). Isolated deficiencies in complex I or complex IV (cytochrome $c$ oxidase $[\mathrm{COX}]$ ) were the most common mono-enzymopathies. Disease onset was $<2$ years in the majority of participants, except for individuals with COX deficiency whose onset spanned the entire age spectrum (table 3). Molecular analysis revealed that isolated 
Table 2 Demographic, clinical, and genetic characteristics of the 264 North American Mitochondrial Disease Consortium Clinical Registry participants with canonical syndromes

\begin{tabular}{|c|c|c|c|c|c|}
\hline & LS & MELAS & cPEO/cPEO+ & LHON & MERRF \\
\hline & $\mathbf{N}=97$ & $\mathbf{N}=71$ & $\mathrm{~N}=55$ & $\mathbf{N}=\mathbf{2 8}$ & $N=13$ \\
\hline & Frequency (\%) & Frequency (\%) & Frequency (\%) & Frequency (\%) & Frequency (\%) \\
\hline \multicolumn{6}{|l|}{ Sex $^{a}$} \\
\hline Female & $48(49.5)$ & $42(60.0)$ & 37 (67.3) & $5(17.9)$ & $7(53.8)$ \\
\hline Male & $49(50.5)$ & $28(40.0)$ & 18 (32.7) & $23(82.1)$ & $6(46.2)$ \\
\hline Missing & - & 1 & - & - & - \\
\hline \multicolumn{6}{|l|}{ Age at onset ${ }^{a}$} \\
\hline$<2 y$ & $55(61.8)$ & $2(3.1)$ & - & $1(3.7)$ & $4(44.4)$ \\
\hline$\geq 2$ to $<5 y$ & $23(25.8)$ & $1(1.5)$ & $4(9.1)$ & $1(3.7)$ & - \\
\hline$\geq 5$ to $<12 y$ & $7(7.9)$ & $18(27.7)$ & $8(18.2)$ & $4(14.8)$ & $2(22.2)$ \\
\hline$\geq 12$ to $<18 y$ & - & $11(16.9)$ & $8(18.2)$ & $4(14.8)$ & - \\
\hline$\geq 18 y$ & $4(4.5)$ & $33(50.8)$ & $24(54.5)$ & $17(63.0)$ & $3(33.3)$ \\
\hline Missing & 8 & 6 & 11 & 1 & 4 \\
\hline \multicolumn{6}{|l|}{ Organ system involvement } \\
\hline CNS & $87(89.7)$ & $68(95.8)$ & $33(60.0)$ & $18(64.3)$ & $13(100.0)$ \\
\hline Skeletal muscle & $73(75.3)$ & $60(84.5)$ & $53(96.4)$ & $6(21.4)$ & $13(100.0)$ \\
\hline Heart & $10(10.3)$ & $21(29.6)$ & $7(12.7)$ & $3(10.7)$ & $1(7.7)$ \\
\hline Developmental & $91(93.8)$ & $22(31.0)$ & $2(3.6)$ & $3(10.7)$ & $5(38.5)$ \\
\hline Constitutional $^{\mathbf{b}}$ & $34(35.1)$ & $39(54.9)$ & $15(27.3)$ & - & $1(7.7)$ \\
\hline Psychiatric & $10(10.3)$ & $23(32.4)$ & 19 (34.5) & $4(14.3)$ & $4(30.8)$ \\
\hline PNS & $7(7.2)$ & $11(15.5)$ & $10(18.2)$ & $2(7.1)$ & $4(30.8)$ \\
\hline Kidney & $5(5.2)$ & $11(15.5)$ & $2(3.6)$ & $4(14.3)$ & - \\
\hline Liver & $1(1.0)$ & - & - & - & - \\
\hline Gastrointestinal & $26(26.8)$ & $22(31.0)$ & $7(12.7)$ & $1(3.6)$ & $2(15.4)$ \\
\hline \multicolumn{6}{|l|}{ Genetic status } \\
\hline nDNA pathogenic variants & $45(46.4)$ & $1(1.4)$ & $18(32.7)$ & $1(3.6)$ & - \\
\hline mtDNA pathogenic variants & $52(53.6)$ & 70 (98.6) & 37 (67.3) & 27 (96.4) & $13(100.0)$ \\
\hline
\end{tabular}

Abbreviations: $\mathrm{CPEO}=$ chronic progressive external ophthalmoplegia; $\mathrm{LHON}=$ Leber hereditary optic neuropathy; $\mathrm{LS}=$ Leigh syndrome; $\mathrm{MELAS}=$ mitochondrial encephalomyopathy, lactic acidosis, and stroke-like episodes; MERRF = myoclonus epilepsy with ragged red fibers; $\mathrm{mtDNA}=$ mitochondrial DNA; nDNA = nuclear DNA; PNS = peripheral nervous system.

${ }^{a}$ Missing values not included in the percentage denominator.

${ }^{b}$ Includes cachexia, chronic fatigue, short stature (the patient's height is below the 3rd percentile), and thinness (body mass index $<18.5 \mathrm{~kg} / \mathrm{m}^{2}$ ).

complex I participants frequently had pathogenic variants in mtDNA (15/18 participants), whereas participants with COX deficiency commonly had nDNA pathogenic variants $(9 / 14$ participants) (table 3 ). In both groups, the most frequent clinical diagnosis was LS. Participants with combined OxPhos deficiencies presented with a diverse spectrum of clinical diagnoses, with LS being the most common (table 3).

PDC activity was assessed in 213 participants, among whom defects were identified in 44 ( 28 females and 16 males). Age at onset was $<2$ years in 38. PDC deficiency-associated presentations were diverse and included encephalopathy $(14 / 44$, $31.8 \%)$, LS (9/44, 20.5\%), encephalomyopathy (4/44, 9.1\%), multisystemic syndrome $(2 / 44,4.5 \%)$, and cardiomyopathy $(1 / 44,2.3 \%)$ (table 3$)$. Forty-two participants had pathogenic variants in nDNA, predominantly in PDHA1 (35 participants). $\mathrm{CoQ}_{10}$ deficiency was diagnosed in only 2 participants (of 220 tested). TP activity was reduced in 8 participants of over 214 tested; all had pathogenic variants in TYMP. 


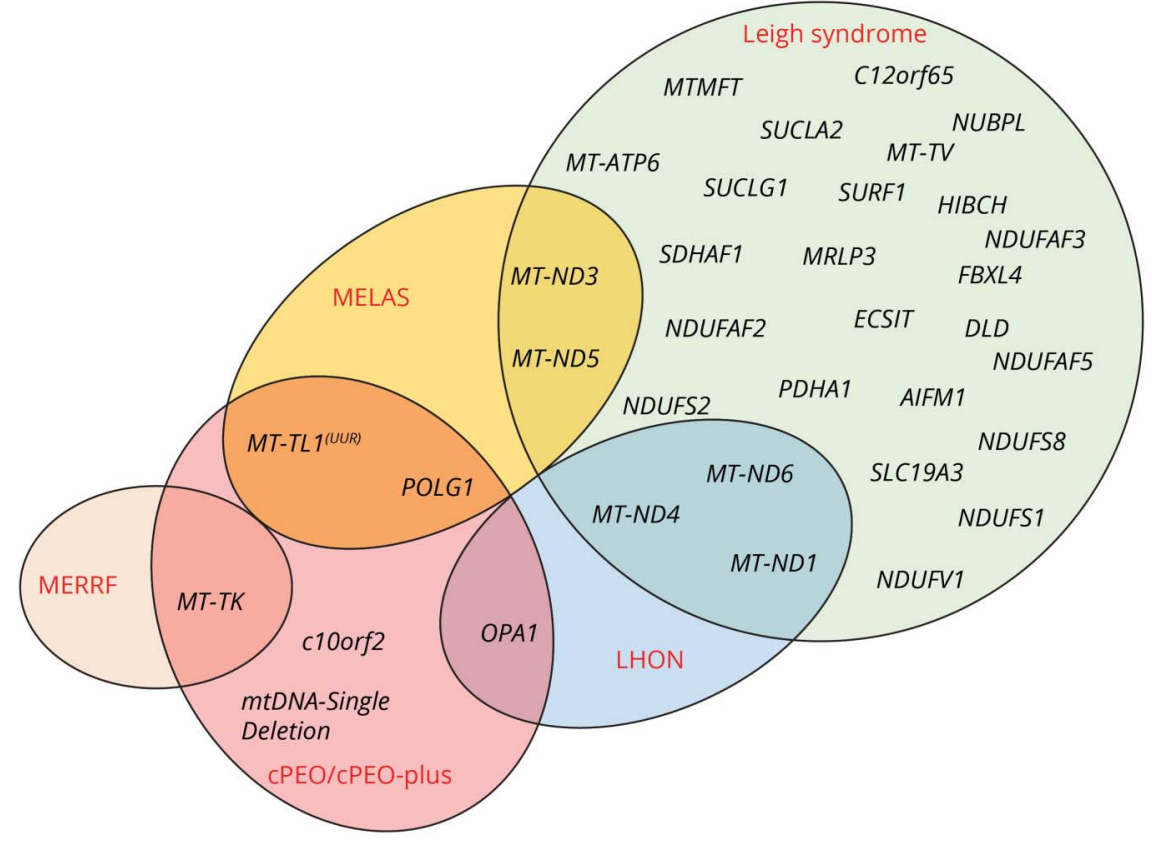

Gene pathogenic variants in North American Mitochondrial Disease Consortium Registry participants with canonical syndromes. CPEO = chronic progressive external ophthalmoplegia; LHON = Leber hereditary optic neuropathy; MELAS = mitochondrial encephalomyopathy, lactic acidosis, and stroke-like episodes; MERRF = myoclonus epilepsy with ragged red fibers; mtDNA = mitochondrial DNA.

\section{Molecular genetics}

mtDNA pathogenic variants were more frequent than nDNA (414 vs 252 participants). mtDNA variants were most prevalent among older patients (38\% of those with onset $\geq 18$ and $22 \%$ of those with onset $<2$ ), whereas nDNA variants were most common in the youngest group (50\% of those with onset $<2$ [table 4]). The most common mtDNA pathogenic variants were $\mathrm{m} .3243 \mathrm{~A}>\mathrm{G}$ in $M T-T L 1$, which encodes tRNA $^{\text {Leu(UUR) }}$ (138 participants) and single deletions (67 participants: table e-2, links.lww.com/NXG/A226). Overall, the distribution of pathogenic variants differed by age $(p<$ 0.0001 , table 4 ). The difference between the youngest and oldest groups was particularly striking. Although nDNA variants were more than twice as frequent as mtDNA among those with onset $<2$ ( $50.4 \%$ vs $22.2 \%)$, the reverse is true in the oldest-onset group (19.3\% mtDNA vs $38.2 \%$ nDNA: post hoc $p<0.0001)$. Pathogenic variants in 65 different nuclear genes were reported (figure 2). Pathogenic variants in 38 genes were reported uniquely in single participants (figure 2).

The early age at onset of participants with nDNA pathogenic variants was associated with a higher frequency of developmental delay (65.5\%) compared with individuals with mtDNA pathogenic variants $(34.8 \%, p<0.0001$ (table 4$)$. In contrast, patients with mtDNA pathogenic variants had higher frequencies of endocrinopathies $(24.6 \%$ vs $9.1 \%, p<$ $0.0001)$ overall and diabetes mellitus in particular (19.1\% vs $2.8 \%, p=0.0001)$. The overall frequencies of CNS manifestations were similar in participants with mtDNA and nDNA pathogenic variants $(82.9 \%$ vs $86.1 \%, p=0.37)$. However, participants with mtDNA variants had higher frequencies of
SLEs $(21.0 \%$ vs $7.1 \%, p<0.0001)$, migraine headaches ( $19.6 \%$ vs $9.9 \%, p=0.02)$, and dementia ( $9.2 \%$ vs $3.2 \%, p=$ 0.04 ), with lower frequencies of upper motor signs (spasticity $[6.8 \%$ vs $15.1 \%, p=0.004]$ and hyperactive reflexes [ $5.6 \%$ vs $13.1 \%, p=0.017]$ ).

\section{Participants with $\mathrm{m} .3243 \mathrm{~A}>\mathrm{G}$}

The m.3243A $>\mathrm{G}$ pathogenic variant was reported in 138 individuals, who were predominantly female ( 89 vs 48 males). Onset of symptoms frequently occurred when participants were age $>18$ years (table e-2, links.lww.com/NXG/A226). Ten different clinical syndromes were observed. The most frequent was MELAS (56 individuals), followed by diabetes and deafness (14 participants), encephalomyopathy (9 participants), and maternally inherited diabetes ( 5 participants). Multisystemic syndrome was diagnosed in 33 participants. CNS was affected in 127 (table e-2) participants, with seizure (55 participants) and migraine (48 participants) as the most common manifestations. Hearing loss was frequently recorded (92 participants), as well as diabetes mellitus that was present in 57 participants.

\section{Participants with $\mathrm{m} .8344 \mathrm{~A}>\mathrm{G}$}

Twenty-three participants had the m.8344A $>\mathrm{G}$ variant (10 males and 13 females) (table e-2, links.lww.com/NXG/ A226). Although the pathogenic variant has been classically associated with MERRF, 7 different phenotypes have been identified in the NAMDC Registry. Nine participants had the diagnosis of MERRF, whereas 9 individuals received other clinical diagnoses. All participants had CNS involvement, with ataxia (15 participants) and myoclonus (16 participants) as 
Table 3 Frequencies of demographic, clinical, and genetic features of participants with specific biochemical diagnoses

\begin{tabular}{|c|c|c|c|c|c|c|c|c|c|}
\hline & Comp I & Comp. II & Comp III & Comp. IV & Comp V & CRCE & $\mathrm{CoQ}_{10}$ & TP & PDC \\
\hline & $18 / 666$ & $1 / 666$ & $1 / 666$ & $14 / 666$ & $5 / 666$ & $21 / 666$ & $2 / 220$ & $8 / 214$ & $44 / 230$ \\
\hline \multicolumn{10}{|l|}{ Sex } \\
\hline Female & 9 & 1 & 1 & 8 & 3 & 12 & 1 & 7 & 28 \\
\hline Male & 9 & - & - & 6 & 2 & 9 & 1 & 1 & 16 \\
\hline \multicolumn{10}{|l|}{ Age at onset } \\
\hline$<2 y$ & 6 & 1 & - & 4 & 3 & 7 & - & 1 & 38 \\
\hline$\geq 2$ to $<5 y$ & - & - & - & 6 & 1 & 5 & 2 & - & 2 \\
\hline$\geq 5$ to $<12 y$ & 3 & - & - & 2 & - & - & - & 1 & 3 \\
\hline$\geq 12$ to $<18 y$ & 1 & - & - & - & - & 1 & - & - & - \\
\hline$\geq 18 y$ & 4 & - & - & 2 & 1 & 8 & - & 5 & - \\
\hline \multicolumn{10}{|l|}{ Clinical syndromes } \\
\hline Multisystemic syndrome & 4 & - & 0 & 3 & 1 & 2 & 1 & - & 2 \\
\hline Other clinical diagnosis & - & - & 1 & 1 & 1 & 1 & - & - & 14 \\
\hline LS & 7 & 1 & - & 5 & 2 & 5 & 1 & - & 9 \\
\hline Encephalomyopathy & - & - & - & 1 & - & 1 & - & - & 4 \\
\hline MELAS & 1 & - & - & - & - & 2 & - & - & - \\
\hline Myopathy & - & - & - & - & - & 1 & - & - & - \\
\hline CPEO+ & - & - & - & 2 & - & 2 & - & - & - \\
\hline Encephalopathy & - & - & - & - & - & 2 & - & - & 14 \\
\hline LHON & 3 & - & - & - & - & - & - & - & - \\
\hline CPEO & - & - & - & - & - & 1 & - & - & - \\
\hline KSS & - & - & - & - & - & 1 & - & - & - \\
\hline SANDO & 1 & - & - & 1 & - & - & - & - & - \\
\hline MIDD & 1 & - & - & - & - & - & - & - & - \\
\hline Alpers syndrome & - & - & - & 1 & - & 1 & - & - & - \\
\hline MNGIE & - & - & - & - & - & - & - & 8 & - \\
\hline $\begin{array}{l}\text { Maternal inherited } \\
\text { deafness }\end{array}$ & - & - & - & - & - & - & - & - & - \\
\hline Cardiomyopathy & - & - & - & - & - & - & - & - & 1 \\
\hline Hepatocerebral syndrome & 1 & - & - & - & - & 2 & - & - & - \\
\hline RIM with COX deficiency & - & - & - & - & 1 & - & - & - & - \\
\hline \multicolumn{10}{|l|}{ Genetic status } \\
\hline $\begin{array}{l}\text { mtDNA pathogenic } \\
\text { variants }\end{array}$ & 15 & - & 1 & 5 & 5 & 13 & 1 & - & 2 \\
\hline nDNA pathogenic variants & 3 & 1 & - & 9 & - & 8 & 1 & 8 & 42 \\
\hline
\end{tabular}

Abbreviations: $\mathrm{COQ}_{10}=$ coenzyme $\mathrm{Q}_{10} ; \mathrm{CPEO}=$ chronic progressive external ophthalmoplegia; $\mathrm{CRCE}=$ combined respiratory chain enzymes; $\mathrm{KSS}=\mathrm{Kearns}-$ Sayre syndrome; LHON = Leber hereditary optic neuropathy; LS = Leigh syndrome; MELAS = mitochondrial encephalomyopathy, lactic acidosis, and strokelike episodes; MIDD = maternal inherited diabetes and deafness; MNGIE = mitochondrial neurogastrointestinal encephalopathy; mtDNA = mitochondrial DNA; nDNA = nuclear DNA; PDC = pyruvate dehydrogenase complex; RIM with COX deficiency = reversible infantile myopathy with cytochrome $c$ oxidase deficiency; SANDO = sensory ataxic neuropathy with dysarthria and ophthalmoparesis; TP = thymidine phosphorylase. 
Table 4 Clinical features of participants with mtDNA pathogenic variants vs nDNA pathogenic variants

\begin{tabular}{|c|c|c|c|}
\hline & mtDNA pathogenic variants $(\mathrm{N}=414)$ & nDNA pathogenic variants $(\mathrm{N}=252)$ & $p$ Value \\
\hline Age at onset & & & $<0.0001$ \\
\hline$<2 y$ & $78(22.2)$ & $120(50.4)$ & \\
\hline$\geq 2$ and $<5 y$ & $40(11.4)$ & $43(18.1)$ & \\
\hline$\geq 5$ and $<12 y$ & $66(18.8)$ & $10(4.2)$ & \\
\hline$\geq 12$ and $<18 y$ & $33(9.4)$ & $19(8.0)$ & \\
\hline$\geq 18 y$ & $134(38.2)$ & $46(19.3)$ & \\
\hline Missing & 63 & 14 & \\
\hline $\operatorname{Sex}^{a}$ & & & 0.37 \\
\hline Male & $183(44.3)$ & $102(40.5)$ & \\
\hline Female & $230(55.7)$ & $150(59.5)$ & \\
\hline Missing & 1 & - & \\
\hline \multicolumn{4}{|l|}{ Organ system manifestations } \\
\hline $\mathrm{CNS}^{\mathbf{b}}$ & $343(82.9)$ & $217(86.1)$ & \\
\hline Seizures & $126(30.4)$ & $101(40.1)$ & 0.16 \\
\hline Ataxia & $126(30.4)$ & $98(38.9)$ & 0.15 \\
\hline SLE & $87(21.0)$ & $18(7.1)$ & $<0.0001$ \\
\hline Migraine headaches & $81(19.6)$ & $25(9.9)$ & 0.02 \\
\hline Myoclonic seizures & $23(5.6)$ & $27(10.7)$ & 1.00 \\
\hline Dysarthria & $68(16.4)$ & $56(22.2)$ & 0.36 \\
\hline Hearing loss & $160(38.6)$ & $46(18.3)$ & $<0.0001$ \\
\hline Hyperactive reflexes & $23(5.6)$ & $33(13.1)$ & 0.017 \\
\hline Other neurologic manifestation & $135(32.6)$ & 99 (39.3) & 0.73 \\
\hline Myoclonus & $41(9.9)$ & $28(11.1)$ & 1.00 \\
\hline Dystonia & $41(9.9)$ & $41(16.3)$ & 0.16 \\
\hline Dementia & $38(9.2)$ & $8(3.2)$ & 0.042 \\
\hline Encephalopathy & $37(8.9)$ & $39(15.5)$ & 0.15 \\
\hline Chorea & $15(3.6)$ & $15(6.0)$ & 0.73 \\
\hline Spasticity & $28(6.8)$ & $38(15.1)$ & 0.0042 \\
\hline Parkinsonism & $5(1.2)$ & $7(2.8)$ & 0.73 \\
\hline PNS $^{\mathbf{b}}$ & $51(12.3)$ & $59(23.4)$ & \\
\hline Axonal & $39(9.4)$ & $42(16.7)$ & 0.0078 \\
\hline Demyelinating & $18(4.3)$ & $24(9.5)$ & 0.0078 \\
\hline Ophthalmoparesis & $75(18.1)$ & $62(24.6)$ & 0.09 \\
\hline Ptosis & $126(30.4)$ & $70(27.8)$ & 0.48 \\
\hline DM & 79 (19.1) & $7(2.8)$ & $<0.0001$ \\
\hline Short stature & $104(25.1)$ & $63(25.0)$ & 1.00 \\
\hline Myopathy & $134(32.4)$ & $72(28.6)$ & 0.29 \\
\hline Developmental & $144(34.8)$ & $165(65.5)$ & $<0.0001$ \\
\hline
\end{tabular}


Table 4 Clinical features of participants with mtDNA pathogenic variants vs nDNA pathogenic variants (continued)

\begin{tabular}{llll}
\hline & mtDNA pathogenic variants $(\mathbf{N}=\mathbf{4 1 4})$ & nDNA pathogenic variants (N=252) & $\boldsymbol{p}$ Value \\
\hline Anxiety & $67(16.2)$ & $35(13.9)$ & 0.73 \\
\hline Depression & $74(17.9)$ & $32(12.7)$ & 0.18 \\
\hline Bipolar disorder & $9(2.2)$ & $6(2.4)$ & 0.79 \\
\hline Gastrointestinal & $97(23.4)$ & $68(27.0)$ & 0.31 \\
\hline Endocrine $^{c}$ & $102(24.6)$ & $23(9.1)$ & $<0.0001$ \\
\hline
\end{tabular}

Abbreviations: $\mathrm{DM}$ = diabetes mellitus; mtDNA = mitochondrial DNA; nDNA = nuclear DNA; PNS = peripheral nervous system; SLE = stroke-like episode.

${ }^{a}$ Missing values not included in the percentage denominator.

b $p$ Values are adjusted for 16 comparisons for CNS and 2 for PNS, using the Holm method. ${ }^{29}$

'Includes diabetes mellitus, hypothyroidism, hypogonadotropic, hypogonadism, hypoparathyroidism, and adrenal insufficiency.

the most common manifestations (table e-2). Skeletal muscle weakness was reported in 21 participants.

\section{Single large-scale mtDNA deletion (mtDNA $\Delta$ )}

$\mathrm{mtDNA} \Delta$ was reported in 67 participants $(29$ males and 38 females) (table e-2, links.lww.com/NXG/A226) with a large spectrum of clinical syndromes (10 different diagnoses), including Kearns-Sayre syndrome (16 individuals), cPEO+ (15 individuals), cPEO (12 individuals), and Pearson syndrome (9 individuals). Skeletal muscle $(58 / 67,86.6 \%)$ and CNS symptoms (44 participants) were prevalent (table e-2). Ptosis (47 participants) and ophthalmoparesis (38 participants) were frequently reported (table e-2). Hearing loss was less common (18 individuals).

\section{Participants with POLG1 pathogenic variants}

Seventy participants ( 25 males and 45 females) had pathogenic variants in POLG1 (figure 2). Onset of symptoms occurred from infancy through late adulthood (range $<1-53$ years). Twenty-four pathogenic variants were observed, distributed along the entire gene and with a high frequency in the linker region. Clinical presentation encompassed 11 different syndromes. Sensory ataxic neuropathy with dysarthria and

Figure 2 Nuclear gene pathogenic variant frequency in the North American Mitochondrial Disease Consortium Registry

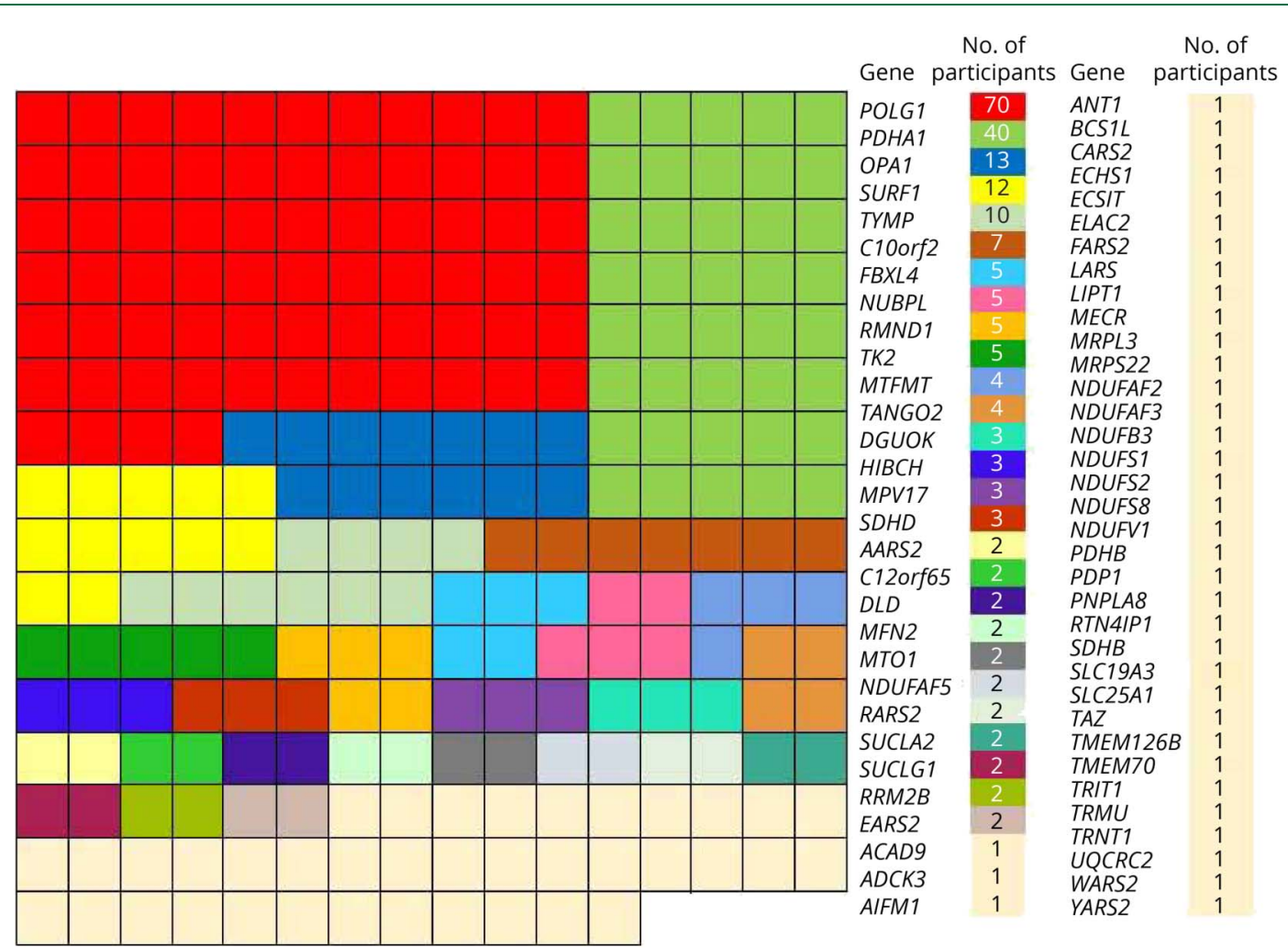

Each square represents 1 participant. 
ophthalmoparesis (SANDO) (18 participants) and Alpers syndrome (14 participants) were the most frequent. Ten had SLEs. Seventeen participants had generic diagnoses of multisystemic or other clinical syndrome. Of interest, phenotype variability was observed in the 10 participants with the homozygous p.A467T pathogenic variant (2 Alpers-Huttenlocher syndrome, 4 SANDO, $1 \mathrm{cPEO}+$, and 3 nonspecific clinical syndromes). Almost all the POLG1 participants $(66 / 70)$ had CNS involvement. Skeletal muscle (61/70 participants) and peripheral nerve (33 participants) were often affected. The most frequent CNS symptoms were ataxia (45/70 participants) and seizures (41/70 participants).

\section{Participants with PDHA1 pathogenic variants}

PDHA1 pathogenic variants were identified in 40 participants ( 11 males and 29 females) (figure 2). Age at onset was $<2$ years in the majority (33/40 individuals). Developmental delay was observed in most participants (36/40), but information about this manifestation was unavailable for 3 participants. Developmental delay was absent in only 1 . Encephalopathy (13/40 participants) and LS (7/40 participants) were the most commonly diagnoses. CNS was affected in 33 individuals, with seizure (21/41 participants) being the most common manifestation.

\section{Participants with OPA1 pathogenic variants}

Of the 13 participants with OPA1 pathogenic variants, 8 had optic atrophy, and 2 were diagnosed as optic atrophy type 1 (autosomal dominant optic atrophy Kjer type). One participant was inappropriately given a clinical diagnosis of LHON before the mtDNA mutation was identified. Ten participants had manifestations outside of the optic nerve including ptosis (4), ophthalmoparesis (4), hearing loss (4), seizures (3), ataxia (3), peripheral neuropathy (2), and dilated cardiomyopathy (1); hence, those patients were given non-autosomal dominant optic atrophy diagnoses (multisystemic disease, cPEO plus, and encephalomyopathy).

\section{Discussion}

Clinical registries are essential for collecting data on rare diseases; those data can be critical for guiding their diagnoses and care. This study, using data from the NAMDC Registry, is the first to depict the spectrum of mitochondrial disorders in North America.

Although participants in the Registry can be enrolled based on clinical manifestations (a genetic diagnosis is not required), this analysis considers only participants with a definite genetic diagnosis. Nonetheless, it is worth highlighting the complexity of the diagnostic pathway in these patients. Indeed, even in the era of next-generation sequencing, ${ }^{13}$ and similarly to other large cohort studies, ${ }^{14,15}$ the NAMDC Registry shows a molecular diagnostic rate of $53.8 \%$ (722 participants of 1,341 received a genetic diagnosis) (table e-3, links.lww.com/NXG/A226).

MtDs have diverse clinical presentations, ${ }^{16}$ which our analysis confirms with 24 different clinical entities. Of interest, many participants are classified outside the classical mitochondrial phenotypes with multisystemic syndrome (113 participants) the most common diagnosis. Sex stratification shows a slight preponderance of females, although the data do not include asymptomatic carriers. Also noteworthy is the skewed racial composition. The majority of participants are Caucasian $(>85 \%)$, whereas $<3 \%$ were African Americans, and $<4 \%$ were Asian. In contrast, the 2010 US Census identified $72.4 \%$ Caucasian, 12.6\% African American, and 4.8\% Asian. Several factors may contribute to this disparity, and although we cannot exclude a recruiting bias, biological factors may play a role in disease susceptibility of some populations. ${ }^{17}$

Because MtDs are typically due to defects in energy metabolism, the Registry includes data on biochemical defects. Enzyme activity assay helps to direct molecular analyses and to identify participants eligible for future therapies targeting specific enzymatic defects. ${ }^{18,19}$ Among the many such defects, OxPhos deficiency has historically been considered the hallmark of MtDs. ${ }^{7}$ In the Registry, the majority of the participants had an OxPhos defect, followed by PDC deficiency. Participants with OxPhos defects most frequently presented with multisystemic diseases. This may reflect the complex genetic control of the respiratory chain machinery. ${ }^{20,21} \mathrm{Re}$ markably few participants had complex $\mathrm{V}$ defects, possibly due to low frequency, detection difficulty, or both.

To portray the features of classic mitochondrial syndromes is extremely important as new therapeutic strategies approach the patient bedside.

Participants with MELAS were prevalent in our cohort. Although previous studies have suggested that male sex may represent a risk factor for development of a full-blown MELAS syndrome, we did not observe a difference by sex in our population. Moreover, the ratio of males was similar among participants with the m.3243A $>\mathrm{G}$ variant $(35 \%)$ and those with a diagnosis of MELAS (40\%) (table e-2, links.lww. com/NXG/A226). In contrast to data obtained in other studies, ${ }^{22}$ MELAS was the most common diagnosis in participants carrying the m.3243A $>\mathrm{G}$ variant. The high proportion of participants with MELAS in the NAMDC may be due to ascertainment bias because some of the NAMDC sites have research projects on this disorder. ${ }^{23}$

Our data also confirm the relatively low prevalence of complete MERRF syndrome. Previous reports from the German and Italian registries showed that only half of the participants with the m.8344A $>\mathrm{G}$ pathogenic variant have classic MERRF syndrome. ${ }^{24}$ The same proportion is observed in our cohort. Of interest, the age at onset in our MERRF cohort is younger than reported elsewhere, with an age at onset before 12 years of age in 6 of 9 participants with available data. We identified hearing loss in $56.5 \%$ of our participants with the m.8344A $>\mathrm{G}$ variant and $46.2 \%$ with MERRF (table e-2, links.lww.com/ NXG/A226). This is in line with some other studies but lower than the German registry data. ${ }^{25,26}$ 
$\mathrm{cPEO} / \mathrm{cPEO}+$ diagnoses are common but less frequent than in previous reports. ${ }^{15}$ This discrepancy may have arisen because the NAMDC Registry includes the multisystemic syndrome category into which multiple complex cPEO+ participants were classified.

The Registry data highlight the vast genetic heterogeneity of the patients with MtDs. We observed a higher frequency of mtDNA pathogenic variants over nDNA (table 4 ). The combination of pediatric and adult clinics in the NAMDC facilitates a comprehensive analysis across the $\mathrm{MtD}$ population. This may help explain why the proportions of mtDNA and nDNA variants in the Registry differ from those in other recent reports. ${ }^{27}$ Other factors such as accessibility and feasibility of mtDNA testing may also have an impact. In the Registry, participants with nDNA pathogenic variants had earlier disease onset than participants with mtDNA pathogenic variants, with onset before age 2 years in $50.4 \%$ individuals (table 4 ). We observed no differences in ptosis and ophthalmoparesis between the 2 groups, in contrast to what was observed in the Italian registry. ${ }^{15}$ High frequencies of SLE, diabetes mellitus, and deafness in mtDNA participants were present, probably due to common mtDNA pathogenic variant-associated phenotypes. The higher frequency of developmental abnormalities in the nDNA subgroup confirms previous data ${ }^{27}$ and is concordant with the younger age at onset.

The identification in our cohort of several genes mutated only in single individuals corroborates the ultra-rare nature of many MtDs genotypes.

This study provides the first wide-ranging look at the $\mathrm{MtD}$ population in North America. The data also identify areas of the Registry that require further improvement. Given the estimated prevalence of $\mathrm{MtDs},{ }^{28}$ it is likely that only a small proportion of North American participants has been captured. To address this limitation, the NAMDC has developed a remote enrollment system to reach patients living in areas distant from a NAMDC center. In addition, the NAMDC has created disease-specific natural history subregistries and other studies that will improve the acquisition of longitudinal data and help to identify outcome measures for future clinical trials.

\section{Acknowledgment}

The authors acknowledge the contributions of the participants and families who have participated in the Registry and of Amy Holbert, Health Informatics Institute/ RDCRN, University of South Florida, for administrative support. In addition, they acknowledge the efforts of the study coordinators.

\section{Study funding}

The project was funded by NIH U54 NS078059. The North American Mitochondrial Disease Consortium (NAMDC) is part of Rare Diseases Clinical Research Network (RDCRN), an initiative of the Office of Rare Diseases Research (ORDR), National Center for Advancing Translational Sciences (NCATS). The project was funded by NIH U54 NS078059, sponsored by the NINDS, the Eunice Kennedy Shriver National Institute of Child Health and Development (NICHD), the Office of Dietary Supplements (ODS), and NCATS. In addition, the NAMDC has received private funding from the United Mitochondrial Disease Foundation (UMDF), a Patient Advocacy Group (PAG) for individuals with mitochondrial disease and their family members, as well as the J. Willard and Alice S. Marriott Family Foundation.

\section{Disclosure}

Disclosures available: Neurology.org/NG.

\section{Publication history}

Received by Neurology: Genetics June 13, 2019. Accepted in final form December 16, 2019.

\begin{tabular}{|c|c|c|}
\hline Author & Institution & Contribution \\
\hline $\begin{array}{l}\text { Emanuele } \\
\text { Barca, MD, } \\
\text { PhD }\end{array}$ & $\begin{array}{l}\text { Department of Neurology, } \\
\text { Columbia University } \\
\text { Medical Center, NY }\end{array}$ & $\begin{array}{l}\text { Data analysis, manuscript } \\
\text { preparation, } \\
\text { communication among } \\
\text { canters, and study design }\end{array}$ \\
\hline $\begin{array}{l}\text { Yuelin Long, } \\
\text { MS }\end{array}$ & $\begin{array}{l}\text { Department of } \\
\text { Biostatistics, Mailman } \\
\text { School of Public Health, } \\
\text { Columbia University, New } \\
\text { York }\end{array}$ & Statistical analysis \\
\hline $\begin{array}{l}\text { Victoria } \\
\text { Cooley, MS }\end{array}$ & $\begin{array}{l}\text { Department of } \\
\text { Biostatistics, Mailman } \\
\text { School of Public Health, } \\
\text { Columbia University, New } \\
\text { York }\end{array}$ & Statistical analysis \\
\hline $\begin{array}{l}\text { Robert } \\
\text { Schoenaker, } \\
\text { MD, BS }\end{array}$ & $\begin{array}{l}\text { Radboudumc, Nijmegen, } \\
\text { The Netherlands }\end{array}$ & $\begin{array}{l}\text { Manuscript preparation } \\
\text { and data analysis }\end{array}$ \\
\hline $\begin{array}{l}\text { Valentina } \\
\text { Emmanuele, } \\
\text { MD, PhD }\end{array}$ & $\begin{array}{l}\text { Department of Neurology, } \\
\text { Columbia University } \\
\text { Medical Center, NY }\end{array}$ & $\begin{array}{l}\text { Data analysis, } \\
\text { communication among } \\
\text { centers, and critical data } \\
\text { review }\end{array}$ \\
\hline $\begin{array}{l}\text { Salvatore } \\
\text { DiMauro, MD }\end{array}$ & $\begin{array}{l}\text { Department of Neurology, } \\
\text { Columbia University } \\
\text { Medical Center, NY }\end{array}$ & $\begin{array}{l}\text { Data analysis, study } \\
\text { design, and critical data } \\
\text { review }\end{array}$ \\
\hline $\begin{array}{l}\text { Bruce H. } \\
\text { Cohen, MD }\end{array}$ & $\begin{array}{l}\text { Department of Pediatrics, } \\
\text { Northeast Ohio Medical } \\
\text { University and Akron } \\
\text { Children's Hospital }\end{array}$ & Provided participant data \\
\hline
\end{tabular}

\begin{tabular}{lll}
\hline Amel Karaa, & Genetics Unit, & Provided participant data \\
MD & $\begin{array}{l}\text { Massachusetts General } \\
\text { Hospital, Boston }\end{array}$
\end{tabular}

\begin{tabular}{lll}
\hline $\begin{array}{l}\text { Georgirene D. } \\
\text { Vladutiu, PhD }\end{array}$ & $\begin{array}{l}\text { Department of Pediatrics, } \\
\text { State University of New } \\
\text { York at Buffalo }\end{array}$ & Provided participant data \\
\hline $\begin{array}{l}\text { Richard Haas, } \\
\text { MBBChir }\end{array}$ & $\begin{array}{l}\text { Departments of } \\
\text { Neurosciences and } \\
\text { Pediatrics, University of } \\
\text { California at San Diego }\end{array}$ & Provided participant data \\
\hline
\end{tabular}

Continued 
Appendix (continued)

\begin{tabular}{|c|c|c|}
\hline Author & Institution & Contribution \\
\hline $\begin{array}{l}\text { Johan L.K. Van } \\
\text { Hove, MD, } \\
\text { PhD }\end{array}$ & $\begin{array}{l}\text { Department of Pediatrics, } \\
\text { University of Colorado } \\
\text { School of Medicine, } \\
\text { Aurora }\end{array}$ & Provided participant data \\
\hline $\begin{array}{l}\text { Fernando } \\
\text { Scaglia, MD }\end{array}$ & $\begin{array}{l}\text { Department of Molecular } \\
\text { and Human Genetics, } \\
\text { Baylor College of Medicine, } \\
\text { Houston, TX; Texas } \\
\text { Children's Hospital, } \\
\text { Houston; Joint BCM-CUHK } \\
\text { Center of Medical Genetics, } \\
\text { Prince of Wales Hospital, } \\
\text { ShaTin, New Territories, } \\
\text { Hong Kong }\end{array}$ & Provided participant data \\
\hline
\end{tabular}

Sumit Parikh, Department of Neurology, Provided participant data MD Cleveland Clinic, $\mathrm{OH}$

\begin{tabular}{ll}
\hline Jirair K. & Departments of Genetics \\
Bedoyan, MD, & and Genome Sciences and \\
PhD & Pediatrics, and Center for \\
& Human Genetics, University \\
& Hospitals Cleveland \\
& Medical Center, Case \\
& Western Reserve \\
& University, OH
\end{tabular}

\begin{tabular}{lll}
\hline Susanne D. & Departments of Genetics & Provided participant data \\
DeBrosse, MD & and Genome Sciences and \\
& Pediatrics, and Center for \\
& Human Genetics, University \\
& Hospitals Cleveland Medical \\
& Center, Case Western \\
& Reserve University, OH
\end{tabular}

\begin{tabular}{lll}
\hline Ralitza H. & Departments of & Provided participant data \\
Gavrilova, MD & Neurology and Clinical \\
& Genomics, Mayo Clinic, \\
& Rochester, MN
\end{tabular}

\begin{tabular}{|c|c|c|}
\hline $\begin{array}{l}\text { Russell P. } \\
\text { Saneto, DO, } \\
\text { PhD }\end{array}$ & $\begin{array}{l}\text { Department of Neurology, } \\
\text { University of Washington, } \\
\text { Seattle Children's Hospital }\end{array}$ & Provided participant data \\
\hline $\begin{array}{l}\text { Gregory M. } \\
\text { Enns, MBChB }\end{array}$ & $\begin{array}{l}\text { Department of Pediatrics, } \\
\text { Stanford University, Palo } \\
\text { Alto, CA }\end{array}$ & Provided participant data \\
\hline $\begin{array}{l}\text { Peter W. } \\
\text { Stacpoole, } \\
\text { MD, PhD }\end{array}$ & $\begin{array}{l}\text { Department of Medicine, } \\
\text { University of Florida at } \\
\text { Gainesville }\end{array}$ & Provided participant data \\
\hline $\begin{array}{l}\text { Jaya Ganesh, } \\
\text { MD }\end{array}$ & $\begin{array}{l}\text { Department of Pediatrics, } \\
\text { Cooper University } \\
\text { Hospital, Camden, NJ }\end{array}$ & Provided participant data \\
\hline $\begin{array}{l}\text { Austin } \\
\text { Larson, MD }\end{array}$ & $\begin{array}{l}\text { Department of Pediatrics, } \\
\text { University of Colorado } \\
\text { School of Medicine, } \\
\text { Aurora }\end{array}$ & Provided participant data \\
\hline $\begin{array}{l}\text { Zarazuela } \\
\text { Zolkipli- } \\
\text { Cunningham, } \\
\text { MD }\end{array}$ & $\begin{array}{l}\text { Mitochondrial Medicine } \\
\text { Frontier Program, Division } \\
\text { of Human Genetics, The } \\
\text { Children's Hospital of } \\
\text { Philadelphia and } \\
\text { University of Pennsylvania } \\
\text { Perelman School of } \\
\text { Medicine; University of } \\
\text { Pennsylvania Perelman } \\
\text { School of Medicine, } \\
\text { Philadelphia }\end{array}$ & Provided participant data \\
\hline
\end{tabular}

Appendix (continued)

\begin{tabular}{lll}
\hline Author & Institution & Contribution \\
\hline Marni J. Falk, & Mitochondrial Medicine & Provided participant data \\
MD & $\begin{array}{l}\text { Frontier Program, Division } \\
\text { of Human Genetics, The }\end{array}$ & \\
& Children's Hospital of & \\
& Philadelphia and University \\
& of Pennsylvania Perelman \\
& School of Medicine &
\end{tabular}

\begin{tabular}{ll}
\hline Amy C. & Mitochondrial Medicine \\
Goldstein, MD & Frontier Program, Division participant data \\
& of Human Genetics, The \\
& Children's Hospital of \\
& Philadelphia and \\
& University of Pennsylvania \\
& Perelman School of \\
& Medicine
\end{tabular}

\begin{tabular}{|c|c|c|}
\hline $\begin{array}{l}\text { Mark } \\
\text { Tarnopolsky, } \\
\text { MD, PhD }\end{array}$ & $\begin{array}{l}\text { Department of Neurology, } \\
\text { McMasters University, } \\
\text { Toronto, ON, Canada }\end{array}$ & Provided participant data \\
\hline $\begin{array}{l}\text { Andrea } \\
\text { Gropman, MD }\end{array}$ & $\begin{array}{l}\text { Children's National } \\
\text { Medical Center }\end{array}$ & Provided participant data \\
\hline $\begin{array}{l}\text { Kathryn } \\
\text { Camp, MS, RD }\end{array}$ & $\begin{array}{l}\text { Office of Dietary } \\
\text { Supplements, National } \\
\text { Institutes of Health, } \\
\text { Bethesda, MD }\end{array}$ & Critical data review \\
\hline $\begin{array}{l}\text { Danuta } \\
\text { Krotoski, PhD }\end{array}$ & $\begin{array}{l}\text { Eunice Kennedy Shriver } \\
\text { National Institute of Child } \\
\text { Health and Human } \\
\text { Development, National } \\
\text { Institutes of Health, } \\
\text { Bethesda, MD }\end{array}$ & Critical data review \\
\hline $\begin{array}{l}\text { Kristin } \\
\text { Engelstad, MS }\end{array}$ & $\begin{array}{l}\text { Department of Neurology, } \\
\text { Columbia University } \\
\text { Medical Center, NY }\end{array}$ & Provided participant data \\
\hline
\end{tabular}

Xiomara Q. Department of Neurology, Provided participant data Rosales, MD Columbia University Medical Center, NY

\begin{tabular}{|c|c|c|}
\hline $\begin{array}{l}\text { Joshua Kriger, } \\
\text { MS }\end{array}$ & $\begin{array}{l}\text { Department of } \\
\text { Biostatistics, Mailman } \\
\text { School of Public Health, } \\
\text { Columbia University, New } \\
\text { York }\end{array}$ & Statistical analysis \\
\hline $\begin{array}{l}\text { Johnston } \\
\text { Grier, MS }\end{array}$ & $\begin{array}{l}\text { Department of } \\
\text { Biostatistics, Mailman } \\
\text { School of Public Health, } \\
\text { Columbia University, New } \\
\text { York }\end{array}$ & Provided participant data \\
\hline $\begin{array}{l}\text { Richard } \\
\text { Buchsbaum }\end{array}$ & $\begin{array}{l}\text { Department of } \\
\text { Biostatistics, Mailman } \\
\text { School of Public Health, } \\
\text { Columbia University, New } \\
\text { York }\end{array}$ & $\begin{array}{l}\text { Database curation and } \\
\text { data set preparation }\end{array}$ \\
\hline $\begin{array}{l}\text { John L.P. } \\
\text { Thompson, } \\
\text { PhD }\end{array}$ & $\begin{array}{l}\text { Department of } \\
\text { Biostatistics, Mailman } \\
\text { School of Public Health, } \\
\text { Columbia University, New } \\
\text { York }\end{array}$ & $\begin{array}{l}\text { Statistical analysis, } \\
\text { manuscript preparation, } \\
\text { and study design }\end{array}$ \\
\hline $\begin{array}{l}\text { Michio } \\
\text { Hirano, MD }\end{array}$ & $\begin{array}{l}\text { Department of Neurology, } \\
\text { Columbia University } \\
\text { Medical Center, NY }\end{array}$ & $\begin{array}{l}\text { Data analysis, manuscript } \\
\text { preparation, } \\
\text { communication among } \\
\text { centers, study design, and } \\
\text { critical data review }\end{array}$ \\
\hline
\end{tabular}




\section{References}

1. DiMauro S, Davidzon G. Mitochondrial DNA and disease. Ann Med 2005;37: 222-232.

2. McFarland R, Taylor RW, Turnbull DM. A neurological perspective on mitochondrial disease. Lancet Neurol 2010;9:829-840.

3. Chinnery PF. Mitochondrial disorders overview. In: Adam MP, Ardinger HH, Pagon RA, et al, editors. GeneReviews ${ }^{\circledast}$. Seattle, WA: University of Washington, Seattle; 2014.

4. Gorman GS, Schaefer AM, Ng Y, et al. Prevalence of nuclear and mitochondrial DNA mutations related to adult mitochondrial disease. Ann Neurol 2015;77:753-759.

5. Thompson R, Robertson A, Lochmüller H. Natural history, trial readiness and gene discovery: advances in patient registries for neuromuscular disease. Adv Exp Med Biol 2017;1031:97-124.

6. Louis ED, Mayer SA, Rowland LP. Merritt's Neurology. Philadelphia, PA: Lippincott Williams \& Wilkins; 2016

7. DiMauro S, Schon EA, Carelli V, Hirano M. The clinical maze of mitochondrial neurology. Nat Rev Neurol 2013;9:429-444.

8. Wallace DC, Zheng XX, Lott MT, et al. Familial mitochondrial encephalomyopathy (MERRF): genetic, pathophysiological, and biochemical characterization of a mitochondrial DNA disease. Cell 1988;55:601-610.

9. Hirano M, Ricci E, Koenigsberger MR, et al. MELAS: an original case and clinical criteria for diagnosis. Neuromuscul Disord 1992;2:125-135.

10. Wallace DC, Singh G, Lott MT, et al. Mitochondrial DNA mutation associated with Leber's hereditary optic neuropathy. Science 1988;242:1427-1430.

11. Cohen BH, Chinnery PF, Copeland WC. POLG-related disorders. In: Adam MP, Ardinger HH, Pagon RA, et al, editors. GeneReviews ${ }^{\circledR}$. Seattle, WA: University of Washington, Seattle; 1993.

12. Hirano M. Mitochondrial neurogastrointestinal encephalopathy disease. In: Adam MP, Ardinger HH, Pagon RA, et al, editors. GeneReviews ${ }^{\circledR}$. Seattle, WA: University of Washington, Seattle; 1993.

13. McCormick E, Place E, Falk MJ. Molecular genetic testing for mitochondrial disease: from one generation to the next. Neurotherapeutics 2013;10:251-261.

14. Pronicka E, Piekutowska-Abramczuk D, Ciara E, et al. New perspective in diagnostics of mitochondrial disorders: two years' experience with whole-exome sequencing at a national paediatric centre. J Transl Med 2016;14:174.

15. Orsucci D, Angelini C, Bertini E, et al. Revisiting mitochondrial ocular myopathies: a study from the Italian network. J Neurol 2017;264:1777-1784.
16. Zolkipli-Cunningham Z, Xiao R, Stoddart A, et al. Mitochondrial disease patient motivations and barriers to participate in clinical trials. PLoS One 2018;13:e0197513.

17. Salvatore DiMauro CP. Mitochondrial disorders due to mutations in the mitochondrial genome. In: Rosenberg RN, Pascual JM, editors. Rosenberg's Molecular and Genetic Basis of Neurological and Psychiatric Disease. 5th Edition. San Diego, CA: Elsevier Science Publishing Co Inc. 2015:271-281.

18. Quinzii CM, Emmanuele V, Hirano M. Clinical presentations of coenzyme q10 deficiency syndrome. Mol Syndromol 2014;5:141-146.

19. Halter JP, Michael W, Schupbach M, et al. Allogeneic haematopoietic stem cell transplantation for mitochondrial neurogastrointestinal encephalomyopathy. Brain 2015;138:2847-2858.

20. Taylor RW, Pyle A, Griffin H, et al. Use of whole-exome sequencing to determine the genetic basis of multiple mitochondrial respiratory chain complex deficiencies. JAMA 2014;312:68-77.

21. Kemp JP, Smith PM, Pyle A, et al. Nuclear factors involved in mitochondrial translation cause a subgroup of combined respiratory chain deficiency. Brain 2011;134: 183-195.

22. Nesbitt V, Pitceathly RD, Turnbull DM, et al. The UKMRC Mitochondrial Disease Patient Cohort Study: clinical phenotypes associated with the m.3243A>G mutation-implications for diagnosis and management. J Neurol Neurosurg Psychiatry 2013;84:936-938.

23. Kaufmann P, Engelstad K, Wei Y, et al. Natural history of MELAS associated with mitochondrial DNA m.3243A >G genotype. Neurology 2011;77:1965-1971.

24. Altmann J, Buchner B, Nadaj-Pakleza A, et al. Expanded phenotypic spectrum of the m.8344A $>$ G "MERRF" mutation: data from the German mitoNET registry. J Neurol 2016;263:961-972.

25. Chinnery PF, Howell N, Lightowlers RN, Turnbull DM. MELAS and MERRF. The relationship between maternal mutation load and the frequency of clinically affected offspring. Brain 1998;121:1889-1894.

26. Mancuso M, Orsucci D, Angelini C, et al. Phenotypic heterogeneity of the $8344 \mathrm{~A}>\mathrm{G}$ mtDNA "MERRF" mutation. Neurology 2013;80:2049-2054.

27. Witters $\mathrm{P}$, Saada A, Honzik T, et al. Revisiting mitochondrial diagnostic criteria in the new era of genomics. Genet Med 2018;20:444-451.

28. Skladal D, Halliday J, Thorburn DR. Minimum birth prevalence of mitochondrial respiratory chain disorders in children. Brain 2003;126:1905-1912.

29. Holm S. A simple sequentially rejective multiple test procedure. Scand J Statist 1979; $6: 65-70$. 


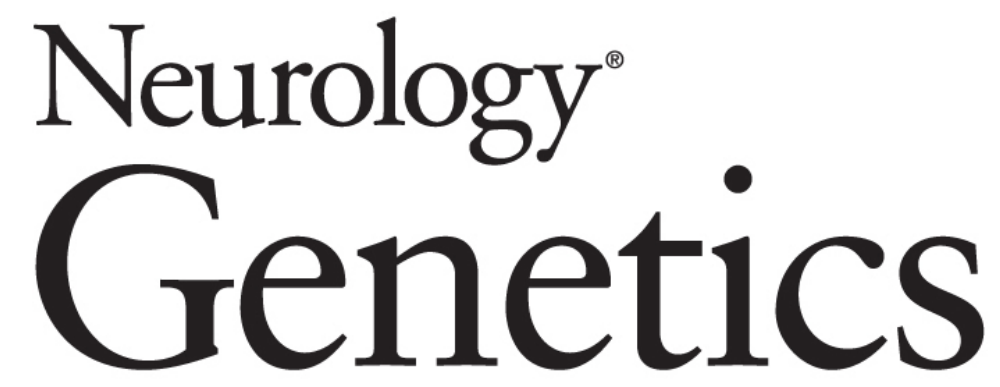

Mitochondrial diseases in North America: An analysis of the NAMDC Registry

Emanuele Barca, Yuelin Long, Victoria Cooley, et al. Neurol Genet 2020;6;

DOI 10.1212/NXG.0000000000000402

This information is current as of March 2, 2020

Neurol Genet is an official journal of the American Academy of Neurology. Published since April 2015, it is an open-access, online-only, continuous publication journal. Copyright Copyright $(2020$ The Author(s). Published by Wolters Kluwer Health, Inc. on behalf of the American Academy of Neurology.. All rights reserved. Online ISSN: 2376-7839.

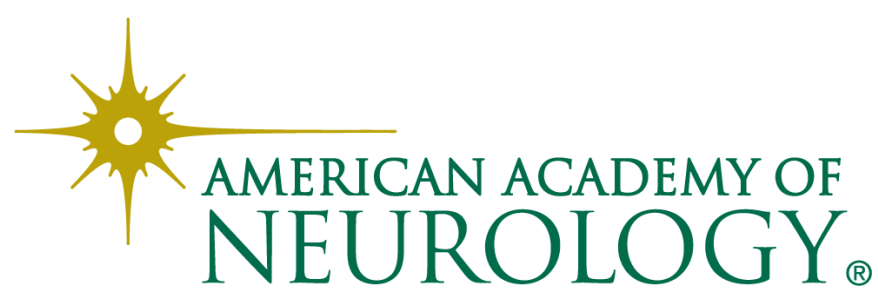




\section{Updated Information \& Services}

References

Subspecialty Collections

Permissions \& Licensing

\section{Reprints}

including high resolution figures, can be found at: http://ng.neurology.org/content/6/2/e402.full.html

This article cites 24 articles, 2 of which you can access for free at: http://ng.neurology.org/content/6/2/e402.full.html\#\#ref-list-1

This article, along with others on similar topics, appears in the following collection(s):

\section{Cohort studies}

http://ng.neurology.org//cgi/collection/cohort_studies

Developmental disorders

http://ng.neurology.org//cgi/collection/developmental_disorders

Mitochondrial disorders

http://ng.neurology.org//cgi/collection/mitochondrial_disorders Muscle disease

http://ng.neurology.org//cgi/collection/muscle_disease

Peripheral neuropathy

http://ng.neurology.org//cgi/collection/peripheral_neuropathy

Information about reproducing this article in parts (figures,tables) or in its entirety can be found online at:

http://ng.neurology.org/misc/about.xhtml\#permissions

Information about ordering reprints can be found online:

http://ng.neurology.org/misc/addir.xhtml\#reprintsus

Neurol Genet is an official journal of the American Academy of Neurology. Published since April 2015, it is an open-access, online-only, continuous publication journal. Copyright Copyright $\odot 2020$ The Author(s). Published by Wolters Kluwer Health, Inc. on behalf of the American Academy of Neurology.. All rights reserved. Online ISSN: 2376-7839.

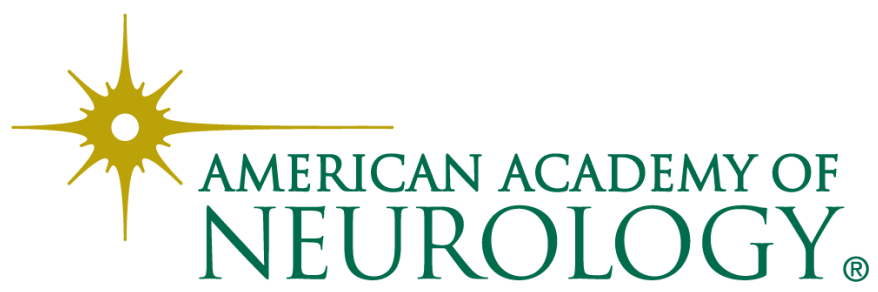

